\title{
Євген МУЛЯРчУК
}

\section{ПОКЛИКАННЯ ЯК МОТИВУЮЧИЙ ЧИННИК РОЗВИТКУ ОСВІТИ В УКРАÏHI}

В статті ставиться проблема нематеріальної мотивації професійної діяльності, зокрема, у сфе-

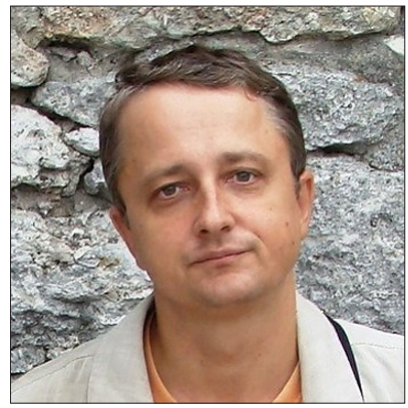
рі освіти. Вирішується завдання виявити значення покликання для учнівської молоді, студентів педагогічного фаху, а також практикуючих учителів. Вивчено мотиви випускників шкіл та студентів щодо освіти та подальшої роботи. Для аналізу безпосереднього досвіду покликання студентів та вчителів застосовується метод глибинних інтерв'ю. В результаті дослідження доведено значимість ідеї покликання для учнівської та студентської молоді в Україні, а також ї релевантність досвіду практикуючих педагогів. Встановлено структуру феномену покликання як єдності елементів: Бажсання-Талант-Реалізація-Благо. Для подальшої дискусії запропоновано визначення поняття покликання. Показано можливі шляхи використання мотиваційного чинника покликання для реформування системи освіти в Україні.

Ключові слова: феномен покликання, самореалізація, досвід, мотивація, відповідальність, суспільна користь, благо, педагогічна діяльність, реформа освіти.

\section{Вступ}

Покликання належить до числа засадничих феноменів культури. Ми говоримо про покликання до художньої творчості, до служіння певній справі у житті, про релігійне покликання людини. Без поняття покликання іноді важко пояснити мотивацію людей до діяльності, яка спрямована в першу чергу на досягнення нематеріальних благ, здійснюється особистістю заради інших людей. Сам феномен покликання, хоч він видається загальнозрозумілим, важко визначити. Однак можливо принаймні описати, як виявляється покликання у «живому» досвіді людей, зокрема у ситуаціях вибору та прийняття рішень щодо професії.

Ми не вдаватимемося тут до грунтовних розвідок в історію виникнення поняття покликання та його поширення в культурі. Це блискуче зробив свого часу М.Вебер. ${ }^{1}$ Ми також не беремося з'ясувати всі можливості

1 Доповіді Макса Вебера «Політика як покликання і професія» та «Наука як покликання і професія» є класичними прикладами розкриття теми покликання. Також М. Вебер застосував концепт покликання в аналізі культурних засад еволюції капіталізму у праці «Протестантська етика і дух капіталізму». 
застосування цього поняття. Наш інтерес є філософським і певною мірою педагогічним. Кожна людина вирішує проблему вибору особистого шляху в житті, самореалізації, сенсу існування. В той чи той спосіб йдеться про професійну або іншу діяльність, яка інтегрує людину у соціальний, культурний чи духовний світ з метою досягнення блага, як його кожен розуміє. Ми маємо показати важливість покликання у житті сучасної людини.

Задум емпіричного дослідження феномену покликання в сучасній Україні виник після ознайомлення з дисертацією Дж.Бігхема «Роль духовності у виборі особистістю педагогічної професії: покликання як мотивуючий чинник» (Liberty University, США, 2008 р.), де було представлено спробу аналізу покликання в аспекті вибору педагогічної професії серед студентів християнського університету. ${ }^{1}$ Українське дослідження відповідає на заклик американського колеги продовжити вивчення феномену покликання у світському вузі. Ми до того ж представляємо інше культурне середовище. В результаті досвід живого спілкування виявився неоціненним для нашого розуміння самого феномену покликання та його значення у практиці освітньої діяльності, чим ми й прагнемо поділитися з читачем,

\section{Актуальність дослідження}

Тема покликання на перший погляд виглядає романтичною та релігійною, чимось з минулого, далекою від того, про що думає сучасна людина. Скептики та прагматики не певні того, що поняття покликання має якийсь реальний зміст, взагалі існує як феномен сучасної секуляризованої людської свідомості. Тому важливо встановити, чи існує феномен покликання у свідомості українців, і як він виявляється.

Чому взагалі потрібно говорити про покликання в наш час? Поперше, через те, що покликання є виявом зрілості та відповідальності особистості у суспільстві. Здатність до свідомого вибору своєї справи у житті, прагнення приносити користь іншим, займати активну позицію у соціальному середовищі необхідні для існування громадянського суспільства як спільноти вільних та відповідальних людей. По-друге, уваги до теми покликання потребують певні сфери суспільного життя та діяльності, де етична, нематеріальна, мотивація особливо важлива. До таких належить галузь освіти. Ї̈і реформування, як і взагалі зміни в Україні, відбудуться завдяки тим, хто повірить у їх можливість, долучиться до них. Оплата праці вчителя та викладача не скоро відповідатиме рівню їі

${ }^{1}$ Див публікацію: Bigham, Jared T. and Smith, Samuel J., "Called to Teach: Interpreting the Phenomenon of Calling as a Motivating Factor" (2008). Faculty Publications and Presentations. Paper 99.

http://digitalcommons.liberty.edu/educ_fac_pubs/99 
суспільного значення. І престиж вчительства є сьогодні швидше уявним, ніж дійсним. Багато успішних студентів педагогічних професій віддають перевагу іншій роботі, внаслідок цього існує проблема недостатності кадрів. У цій ситуації мотивуючий чинник покликання має бути врахованим в розробці програм професійної підготовки та тренінгів, у побудові системи оцінювання та підтримки вчителів. Проблема мотивації в сфері освіти загалом потребує політичної, суспільної та наукової уваги.

\section{Методологія}

Предмет дослідження передбачає феноменологічний аналіз - власне те, як у свідомості людини виявляється певне стійке смислове ціле, якому ми даємо назву «покликання». Методом нашого дослідження та його стратегією є герменевтична феноменологія. Безпосереднє спілкування як спосіб виявлення індивідуального досвіду організовується за методикою глибинних інтерв’ю. Проводячи глибинне інтерв’ю, ми насамперед допомагаємо людині передати та реконструювати іiі досвід, запитуємо, слухаємо, висловлюємо й уточнюємо своє розуміння почутого спільно із співрозмовником. Предмет дослідження знаходиться у колі інтерпретації, коли змінюються рамки його попереднього розуміння і відкривається різноманіття його виявів. В такий спосіб феномен виявляється у світлі розуміння, отримує словесне вираження, набуває формулювання в думці.

Для того, щоб показати присутність ідеї покликання в масовій свідомості, щоб мати якір в незаперечній реальності, глибинним інтерв’ю передував етап опитування учнів шкіл та студентів. Це дало змогу зібрати інформацію про вагу різних можливих факторів вибору професії та про частку тих, хто визнає наявність досвіду покликання. Опитування проводилося на 2-х вибіркових сукупностях. Перша складалася з учнів 10 класів 2-х середніх шкіл м. Києва, друга зі студентів Національного педагогічного університету ім. М.П.Драгоманова. 3 числа останніх запрошувалися учасники глибинних інтерв'ю. Після спілкування зі студентами глибинні інтерв’ю проводилися також із вчителями шкіл.

\section{Опитування випускників шкіл та студентів педагогічного університету}

\section{Учні шкіл}

Опитування про ставлення учнів шкіл до вибору майбутньої професії та роль покликання у цьому було проведене у травні 2016 р. Опитано 105 учнів середніх шкіл шляхом письмового заповнення анкет, розданих у класах. Анкета складалася з питань закритого типу з можливістю обрати кілька альтернатив до деяких з них та дописати власну думку. Питання стосувалися того, чи обрали учні вже майбутню професію, яка роль ро- 
дини у їхньому виборі, які мотиви їхнього вибору, чи відчувають вони покликання до певної роботи або діяльності, і чи потрібно, щоб професія людини співпадала з їі покликанням. Основні отримані результати наводимо узагальнено.

\section{Загальні уявлення щодо майбутньої професї̈:}

1) щонайменше 90\% учнів 10-х класів столиці України збиралися отримати майбутню професію в університетах та коледжах,

2) не менше, ніж 50\% з них перед останнім роком навчання в школі вже вирішили, яку професію вони хочуть здобути,

3) $30 \%$ респондентів обрали професію своїх батьків або близьких родичів.

\section{Мотивація вибору професії:}

1) $70 \%$ опитаних мотивовані матеріальними вигодами від майбутньої професії,

2) майже стільки ж, до 70\%, шукають особистого розвитку у майбутній професії,

3) $30 \%$ учнів зважали на соціальний престиж професії,

4) так само для $30 \%$ майбутня робота - це можливість спілкуватися, бути в середовищі однодумців,

5) ще $30 \%$ заявили, що для них головне - це сам зміст роботи за обраною професією,

6) близько 30-35\% розглядали роботу як можливість бути корисним для суспільства, служити добру у світі.

\section{Покликання до професії:}

1) $33 \%$ учнів відповіли, що відчувають покликання до якоїсь професії або справи у житті,

2) $54 \%$ ще не визначилися щодо свого покликання,

3) $13 \%$ або не розуміли, що означає поняття "покликання", або відповіли що не мають покликання ні до чого,

4) не менше, ніж 50\% учнів згодні з тим, що потрібно обирати професію за покликанням,

5) для інших 45\% необов’язково покликання має співпадати з професією,

6) $5 \%$ не могли дати певної відповіді.

Результати опитування показують, що кожен третій український учень в 16-17 років має уявлення про своє покликання. Не менше половини учнів обиратимуть майбутню професію, керуючись думкою про своє покликання. 30-35\% виявляють альтруїстичну мотивацію і наміри служити суспільній користі та добру при виборі майбутньої професіі. Отже, в цілому можна стверджувати, що тема покликання є зрозумілою для учнівської молоді в Україні, є і має бути предметом обговорення як мотивуючий чинник. 


\section{Студенти університету}

Було опитано 90 студентів 3 курсу педагогічного університету у квітні-травні 2016 р. 3'ясовувалося, чи планують студенти йти на педагогічну роботу після закінчення університету, чи є у них педагоги в родині, чи є обрана професія для них першою, які мотиви вибору їхнього місця навчання, які внутрішні та зовнішні фактори мотивують їх до вчительської роботи, чи відчувають вони покликання до педагогічної роботи, чи потрібно, щоб професія людини співпадала з ії покликанням. Насамкінець, студенти відповідали чи згодні вони взяти участь у глибинних інтерв'ю з теми покликання.

\section{Намір працювати вчителем або викладачем у майбутньому:}

1) $23 \%$ збираються працювати педагогами після університету,

2) $37 \%$ не впевнені, чи підуть працювати вчителями або викладачами,

3) $40 \%$ не збираються працювати за педагогічним фахом.

\section{Причини вступу до педагогічного університету:}

1) $25 \%$ хотіли отримати педагогічну професію,

2) $65 \%$ прийшли, щоб вивчати певний фаховий предмет, такий як мова, література, філософія та ін. без чіткої мети стати вчителем або викладачем,

3) $10 \%$ взагалі не мали інтересу до жодної професії, їх факультет та й сам університет є лише місцем, де порівняно легше здобути вищу освіту після школи.

Вплив родини на вибір навчання в педагогічному університеті значний - $44 \%$ з опитаних студентів мали педагогів у родині. Лише $3 \%$ опитаних студентів мали інші професії до вступу в даний університет. Мотивація до педагогічної професії для більшості є нематеріальною. Респонденти, які збираються стати вчителями або викладачами, переважно не бачать зовнішніх вигід у цій професії. Лише $15 \%$ з усіх опитаних студентів вважають довготривалу літню відпустку важливою перевагою роботи вчителя або викладача. Ще менше, $6 \%$, вважають що педагогічна робота дає повагу та престиж у суспільстві. $21 \%$ усвідомлюють як вигоду цієї професії можливість додаткових заробітків.

Внутрішня мотивація до педагогічної роботи (респонденти мали можливість обрати кілька альтернатив відповідей):

1) $60 \%$ студентів пед. університету стверджують, що їм подобається працювати та спілкуватися з дітьми, з молоддю,

2) $35 \%$ бажають брати участь у вихованні молодих людей,

3) $29 \%$ хочуть бути корисними для суспільства,

4) $18 \%$ відчувають духовне покликання служити добру, давати знання,

5) $17 \%$ перш за все приваблює предмет викладання,

6) $3 \%$ мають релігійне покликання до того, щоб навчати. 


\section{Покликання до вчительської/педагогічної професії:}

1) $25 \%$ респондентів заявляють, що мають покликання до такої професії,

2) $52 \%$ не були впевнені стосовно власного покликання до вчительства,

3) 23\% відповіли категорично, що не мають покликання до педагогічної роботи,

4) $50 \%$ респондентів відповіли, що необхідно обирати професію за покликанням,

5) для $20 \%$ бажано, але необов'язково, щоб покликання і професія співпадали,

6) $30 \%$ вважають, що покликання цілком можна реалізовувати поза професійним заняттям.

Результати опитування показують, що у студентів педагогічних вишів в Україні, на прикладі Національного педагогічного університету ім. М.П.Драгоманова, є найрізноманітніші причини до вибору місця навчання, і не так багато з них, близько 23\%, впевнено збираються ставати вчителями чи займатися іншою педагогічною діяльністю, $37 \%$ непевні у цьому, а $40 \%$ не мають такого наміру. Попри те, що 50\% студентів згаданого університету вважають за потрібне обирати професію за покликанням, вдвічі менший відсоток збираються стати педагогами, а отже, ще $25 \%$ йдуть шляхом реалізації інших покликань. Різноманіття фахових дисциплін і можливостей, які дають університети, в цілому не може вважатися недоліком. Питання спеціалізації педагогічних університетів та цільове використання бюджетного фінансування на розвиток освіти має бути турботою профільного міністерства та адміністрації вишу, а не самих вступників. Студентська молодь, переважно орієнтовна на думку про покликання, і завдання освітньої політики полягає в тому, як цю внутрішню мотивацію спрямувати на користь суспільства та для блага самих молодих людей. Перейдемо до опису процесу та результатів глибинних інтерв’ю.

\section{Глибинні інтерв'ю зі студентами, які виявили власне розуміння покликання}

10 студентів педагогічного університету були запрошені на індивідуальні інтерв'ю, які мали місце в Інституті філософії ім. Г.С.Сковороди НАН України у травні-червні 2016 р. Студенти були з різних факультетів: 5 з іноземної філології, української філології та літературної творчості, 2 з факультету соціально-психологічних наук та управління і 3 з факультету філософської освіти та науки. Всі ці студенти збиралися стати вчителями або педагогами по закінченні університету і вважали, що мають відчуття й розуміння покликання. Всі вони навчалися в кінці 3-го курсу, 
8 було жіночої статі та 2 чоловічої, віком 19-21 років. Територіально - це вихідці з різних частин України. Імена учасників у публікації змінені.

Метою нашого дослідження було перш за все поглибити розуміння феномена покликання. У кожному інтерв’ю ми намагалися виявити, що означає покликання для людини, і поміркувати з нею про різні аспекти його усвідомлення та здійснення. Розмова кожного разу давала можливість прояснити не однаково очевидні для всіх сюжети покликань, які у скороченому вигляді можуть бути представлені у таких темах:

1) Рішення про вступ до університету та вибір педагогічної професії

2) Релігія та духовність як мотивуючі фактори вибору професії

3) Типологія виявлення покликання в індивідуальному досвіді

\section{Рішення про вступ до університету та вибір педагогічної професії}

\section{Педагоги в родині}

Присутність педагогів в родинах є важливим чинником вибору вчительської професії. Попереднє опитування показало, що 2/3 тих студентів, які відчувають покликання до педагогічної професії, були з родин вчителів або викладачів. Це свідчить про те, що покликання переважно сприймають у безпосередньому життєвому середовищі, яким і $є$ родина. Тому не дивно, що 5 з 10 учасників інтерв'ю мали родичів у сфері освіти. Інша половина учасників інтерв'ю були не з учительських чи професорських родин, але деякі з них свідчили, що свого часу хтось з їх батьків не реалізував бажання стати педагогом. Важливою для всіх студентів, хто має відчуття покликання, була відсутність примусу з боку родини. Для когось батьки бачили інші перспективи, але давали свободу вибору.

\section{Добрі приклади та поради поза родиною}

Більшість студентів розповідали, що вони хотіли бути такими, як їхні улюблені вчителі у школах. Приклад шкільного вчителя чи викладача в університеті часто важить більше, ніж вплив родини. Улюблений педагог був джерелом натхнення до вивчення його предмету та рішення вступити в університет для кількох наших співрозмовників. Так само позитивний приклад університетських викладачів утверджував у виборі подальшого шляху. Важливими у виборі фаху були увага і добра порада шкільних психологів або вчителів. Визнання здібностей до чогось конкретного та підтримка з боку інших людей часто потрібні молодій людині для прийняття рішення. Зазвичай це свого роду порада зі спеціалізації у певному полі вже усвідомлених і проявлених інтересів.

\section{Бажсання змінити дійсність}

Це радше нетипова мотивація, але 2 студентів у наших інтерв’ю відзначили, що, спостерігаючи за багатьма випадками неправильного під- 
ходу до вчительської роботи у їхніх школах, вони хотіли стати не такими, як їхні вчителі, робити протилежне. Виникало бажання змінити систему навчання, подолати рутинну практику, внести творчість, готовність допомагати, атмосферу свободи у шкільне життя.

\section{Практичний досвід та інтерес до певного предмету}

Багато хто зі студентів стверджували, що вирішили стати вчителями, оскільки мали власний педагогічний досвід. Це могли бути окремі уроки, допомога іншим учням та інші заходи, які вони проводили у школі, або й уже педпрактика в університеті, досвід чого сподобався та утвердив у рішенні на користь вчительства. Часто студенти вступають до вишу для вивчення певного улюбленого предмету. І лише в університеті, коли вони отримують більше знань та практику викладання, дехто з них вперше усвідомлює, що хоче стати вчителем чи викладачем.

Налаштованість на спілкування з дітьми та виховання молодшого покоління

Справді типовим і частим поясненням вибору вчительської професії $\epsilon$ любов до дітей. Більшість студентів та вчителів, з якими ми спілкувалися на інтерв'ю, казали, що їм подобається бути з дітьми, і що вони хотіли вчити та виховувати дітей. Налаштованість на роботу з дітьми та інтерес до певного предмету є у багатьох випадках важливішими, ніж поради, позитивні чи негативні приклади. Тримання того, що людина любить робити і ким вона хоче бути, $є$ шляхом до власного вірного рішення, i, разом з духом свободи, присутнім і необхідним у цьому, є першою ознакою покликання.

\section{Релігія і духовність як мотивуючі фактори вибору професії}

Вважаємо істотним те, що 5 з 10 студентів, які виявили досвід та розуміння покликання і погодилися прийти на інтерв’ю, визнали, що їх світогляд є певною мірою релігійним. Їх конфесійна належність та залучення до релігійного життя є різними від інтелектуальної віри до активної участі в справах громади віруючих. Троє були православними християнами, одна людина протестантського напрямку віри, ще інший - «деїст» за самовизначенням. Власне ніхто з них не пояснював вибір фаху релігійними мотивами. Релігія формує готовність прийняти покликання, служити певній меті, але не визначає його предмет і напрямок.

У трьох перших респондентів релігійне виховання визначало ставлення до світу, бажання допомагати людям, що лише побічно зумовлювало можливий вибір педагогічної професії. Покликання, на їхню думку, $€$ все ж таки радше особистим вибором і відповідальністю людини, ніж релігійним обов'язком. Інша наша співрозмовниця була схильна по- 
яснювати кожен крок волею «згори». Вона не вважає, що робить вибір сфери діяльності сама. Ї̈̈ суто релігійне відчуття покликання, спрямоване бажанням бути з Богом, спонукає використовувати для цього різні особисті здібності, які можуть послужити духовній меті. Протилежний полюс співвідношення релігійної свідомості та покликання представляє приклад позиції студента «деїста», чи «агностика». Його філософська віра не передбачає пізнання волі Бога або «вищого розуму» стосовно людини. Покликання, з цього погляду, є особистою потребою, і така людина вільно визначається у спрямуваннях своєї діяльності.

Що ж дає релігія людському покликанню? На це питання потрібно відповісти коротко: відчуття істинності та сподівання на його реалізацію. Думка, що певним, можливо непомітним для людини, чином іiі життєвий шлях скеровується «провидінням», стає джерелом впевненості. Ось як звучить це зі слів однієї зі студенток: «Якщо Бог привів мене до цієї професії, то Він допоможе мені впоратися з труднощами».

Взагалі, якщо говорити про людей покликання, вони мало відрізняються залежно від релігійності. У покликанні людина не існує лише для себе самої. Тому ті, хто не бачить впливу релігії на свій життєвий вибір, все ж легко погоджуються назвати свою мотивацію духовною, маючи на увазі мотиви служіння добру, суспільству, ідеалам. Духовність розуміють як внутрішню віру, особисті переконання, моральні цінності на противагу матеріальним потребам. Отже, існує певна спорідненість у покликанні людей релігійних і нерелігійних за світоглядом. I ті, й інші відчувають момент трансцендування, виходу поза особистісні межі у покликанні, хоча й по-різному можуть це пояснювати.

\section{Типологія виявлення покликання в індивідуальному досвіді}

Наші бесіди прямували до того, щоб побачити щось об'єднуюче в особистісному досвіді людей, певну структуру свідомості, смислове ціле, яке ми називаємо «покликанням». Кожному учаснику інтерв’ю пропонувалося сформулювати власне розуміння покликання. Але для допомоги ми мали визначення, наведене в згаданому американському досліджені: «Покликання - це будь-яка кар'єра не мотивована матеріальними чинниками або це діяльність спрямована на покращення суспільства, або ж це результат впливу на людину “вищої сили”. За своєю суттю, це зайняття, яке вимагає певної “жертви” від особистості». ${ }^{1}$ Багато хто з українських студентів відразу визначав покликання як «споріднену працю» згідно з концепцією видатного українського мандрівного

\footnotetext{
${ }^{1}$ Bigham, Jared T. and Smith, Samuel J. Called to Teach: Interpreting the Phenomenon of Calling as a Motivating Factor. - P. 11.
} 
філософа 18 ст. Григорія Сковороди. На думку Сковороди, споріднена праця - це єдиний шлях до щастя. Філософ твердив, що від природи (від Бога) кожна людина має схильність до певної діяльності, але вона буде дійсно щаслива, лише коли узгоджуватиме свою особисту роботу зі спільною, для всіх однаковою справою - пошуком царства Божого. ${ }^{1}$

Однак, розглянемо детальніше, як розуміли покликання самі наші співрозмовники. Можна виділити тут такі визначення: 1) самореалізаційні, 2) просоціальні, 3) трансцендентні.

Самореалізаційна орієнтація спирається на ідеї особистого розвитку, самовиявлення або й захоплення чимось. Покликання в такий спосіб виявляється як конструювання сенсу особистого існування, у процесі якого з'єднуються мотивація до саморозвитку, діяльність та оцінка іiі результату. Таке розуміння апелює до таланту та особистих бажань, які людина вважає за необхідне реалізувати. Наприклад, наша співрозмовниця Олена каже: «Покликання - це те, до чого в людини є інтерес і що їй вдається, тому що вона має до цього здібності». Суб’єктивним критерієм покликання є ії задоволення від самореалізації, а об'єктивним - те, що самореалізація успішної людини сприяє благу інших людей.

Для частини студентів питання покликання - це не внутрішній пошук чи пізнання себе, а самовиявлення. Так Марія визначає покликання через поняття «хист», як природжену здібність до чогось. Якщо людина має хист, це виявляється саме по собі, невимушено: «коли людину спеціально цьому не вчили, але в неї це виходить». Сама Марія вміє лагодити з дітьми, організувати їх, гармонізувати будь-яку ситуацію і скерувати їхні дії швидко та без насильства. «Я можу і не знати, як на психологічному рівні називається той чи той прийом управління, але я знаю, що треба зробити, як заговорити, щоб діти повели себе як належить». Таким чином, виявляється інтуїтивна компетентність у тому, до чого в людини $є$ покликання. Покликання як самовиявлення є активним. Це не просто знання себе кимось, це діяльність у цій сфері. Марія каже: «Якщо ти відчуваєш любов до дітей і не реалізовуєш іiї, тоді це не можна назвати твоїм покликанням. Бо як ти можеш знати, що це твоє покликання, коли ти не дієш в цій сфері?» Покликання мають визнати інші люди. Отже, покликання немов саме виявляється у тій сфері, де людина відчуває себе комфортно, отримує задоволення і визнання від інших.

До визначення покликання ми маємо додати ще й поняття «бажання». Марія каже: «якщо ти робиш щось “через не хочу”, то це не покликання». Схожим чином, через емоційну потребу, формулює визначення

${ }^{1}$ «Щасливий, хто поєднав любу собі роботу із загальною». - Пише Г.С. Сковорода. Див.: Сковорода Григорій. Твори: У 2 т. - К.: АТ «Обереги», 1994. - (Гарвардська б-ка давнього укр. письменства). Т. 1. - С. 116. 
Андрій: «Покликання - це коли ти просто розумієш, що не можеш робити інше». Емоційна потреба усвідомлюється, і в певний момент людина приходить до рішення обирати справу до душі, а не тому, що вона дає якісь зовнішні вигоди. При цьому не талант є початком покликання, а внутрішня потреба людини. Андрій слушно відзначає, що людина може мати різні обдарування і спокійно себе почувати, не реалізовуючи їх. I Марія, і Андрій виходять з розуміння, що покликання - це їх спосіб жити за своїми бажаннями і водночас єдина можливість робити щось корисне у світі, адже споріднена праця не може бути безплідною.

В структурі покликання бажання є початком, але воно веде особистість у світ. Це не ії залежність від себе, це тяжіння до чогось. Особистість існує в улюбленій справі, у тому, від чого вона не хоче відволікатися. Так у покликанні виявляється місце людини у світі. «Мені подобається думати, що у кожного є своє місце у цьому світі, кожна людина може знайти професію для себе, яку вона буде виконувати добре», - каже Софія. Однак, покликання не слід розуміти як лише зачарування, захоплення, яке може минати.

Самореалізаційне розуміння виявляє в структурі покликання єдність елементів: «Бажання-Талант-Реалізація». За словами студентки Тетяни: «Покликання - це стійке бажання, яке потребує реалізації. Не кожен може знайти і зрозуміти це у собі». Отже, для повноти структури покликання замало стійкого бажання, яке ми здатні реалізувати. Власне, чого бракує тим, хто не може знайти і реалізувати себе? Мети, яка завжди надособистісна, передбачає і допускає етичну оцінку, моральне зобов'язання служити певному благу. У досвіді покликання спрямування до саморозвитку та самовиявлення особистості поєднуються з потребою приносити користь суспільству та служити вищим ідеалам. В структурі покликання, виявленого через особистісну самореалізацію, надособистіне благо імпліцитно присутнє, навіть коли на ньому не концентрують увагу. До того ж, сама соціальна організація професійної діяльності допомагає узгодити особисті бажання та суспільні потреби, інституціоналізуючи альтруїстичну поведінку. ${ }^{1}$

Просоціально спрямовані респонденти відразу визначають покликання як служіння іншим людям та суспільству. Допомога людям є для них реалізацією внутрішнього переконання і моральним задоволенням вод-

${ }^{1}$ Як відзначав американський соціолог XX ст. Р.Мертон: «Соціальна конструкція (social invention) професій інституціоналізує альтруїстичну поведінку. Професії не вимагають від тих, хто їх практикує, альтруїстичних почуттів (хоч у цьому не було б нічого поганого); вона вимагає від них діяти альтруїстично (принаймні значною мірою)». Див.: Merton Robert K. Some thoughts on the professions in American society (Address Before The Graduate Convocation Brown University, June 6, 1960). - Brown University Papers Number XXXVII. - P.11. 
ночас. Надія каже: «Покликання - це допомагати людям і отримувати від цього задоволення». Іван твердить: «Покликання приносить людині задоволення і якесь моральне й духовне щастя під час виконання нею своєї роботи». Таке покликання несе у собі і моральну, і естетичну складову - бачити світ довкола кращим, більш гармонійним, щасливим, докладаючи до цього власних зусиль.

Лінія мотивації від особистого бажання до соціального блага легко екстраполюється на благо трансцендентне. Трансцендентне розуміння покладає мету покликання поза конкретним соціальним середовищем і навіть людським світом - це служіння певним ідеям, добру, виконання волі Божої і т. ін. Найпершим прикладом є релігійне покликання. Так студентка Іванна каже: «Покликання - це призначення, яке для тебе задумав Господь». Людина не знає себе до кінця, Бог є умовою її самопізнання і вірного шляху. Покликання в такому разі веде до Бога через все іiі життя. Філософський сенс такого світогляду у тому, що людина обмежена в можливостях пізнання і діяльності, конечна у їі житті, але має прагнення жити, трансцендуючи свої особистісні межі. Інша модальність трансцендентного розуміння покликання - служіння ідеям. Це справедливість у несправедливому суспільстві, служіння добру попри все зло світу і т. ін. Загалом, це спрямування жити за переконаннями, поступатися якими означає для людини більшу втрату, ніж іноді саме іiі життя чи його комфортні умови.

Таким чином, у покликанні нами виділені самореалізаційні, просоціальні та трансцендуючі інтенції. Ми вже відзначили, що ці спрямування поєднуються різною мірою і визначають особливості життєвих позицій людей. Повна смислова конструкція покликання виглядає так: Бажання-Талант-Реалізація-Благо. Під благом ми розуміємо принаймні суспільну користь або позитивне соціальне значення діяльності. Той, чия діяльність не несе безпосередньо або опосередковано користь іншим людям, суспільству, не зможе довести, що це його покликання. Власне доводити це іншим не обов'язково, але необхідно бодай самому вірити в те благо, яке несе в собі твоя справа. А час, можливо, доведе, хибним чи справжнім було таке переконання. Нерідко справдження покликання настає після життя митця, і так є для віруючої людини. У релігійному витлумаченні смисловий конструкт покликання виглядатиме так: Bipa-Дар-Cправи-Духовне благо. Віра є бажанням бути з Богом. Людина реалізує свою віру чи переконання, використовуючи свої таланти-обдарування, у справах-діяльності на користь іншим, «на славу Божу» чи заради ідеї Добра. 


\section{Вчителі про досвід покликання}

У серпні 2016 р. були запрошені до інтерв’ю 5 педагогів київських шкіл. Загалом, спілкування з вчителями не змінило розуміння покликання, отримане в інтерв’ю зі студентами. Це свідчення на користь того, що феномен покликання існує у свідомості молодих людей так само, як і в людей з досвідом. Питання у тому, яким видається шлях у покликані. Тож додамо деякі свідчення життєвої мудрості й осмислення прожитого людьми у професії.

Ірина, вчитель початкової школи, 25 років стажу, звісно, відзначає місію вчителя, його обов'язки перед учнями і суспільством. Але ось так звучить безпосередність емоційного досвіду вчительки: «Я працюю, бо це моє. Я вже до цього звикла, мені вже цього хочеться, я вже без цього не можу». «Хочеться» - просте, але важливе слово, воно описує покликання як те, до чого є внутрішня потреба, без чого людина не радіє життю. Продовжимо цитату: «Робота інколи дає осяяння, є бажання щось донести дітям, хочеться, щоб діти розвивалися, вчилися думати, аналізувати, щоб були вони творчі». Складнощі професії, невластиві вчителеві функції, які доводиться виконувати у школі, не переважують задоволення, яке Ірина отримує від роботи: «Робота окрилює, буває живеш $з$ таким натхненням...» Життя в покликанні не ділиться на роботу і вільний час. Ірина каже: «Сама робота тебе тримає, я не вільна від думок, постійно думаю про цю роботу, але це наповнює».

У покликанні важливе, принаймні суб'єктивне, розуміння користі, яку воно приносить. Ірина веде далі: «Це ти вважаєш, що це приносить користь. Адже, якщо людина зрозуміє, що від цього немає користі, то вона це покине, це не покликання. Просто хотіти і вміти, але не приносити користі людям - це захоплення». Втім, феномен покликання не $є$ суто внутрішнім переживанням. «Це ми не тільки собі придумали, але якийсь поштовх чуєш до цього». Джерело такого зовнішнього спонукання залежить від справи. Для вчителя - це найближче зовнішнє оточення, діти передусім. Це ті, чиї обличчя вчитель має перед своїм мисленим поглядом, від кого «йде поклик», за кого і перед ким вчитель відчуває свою відповідальність.

Покликанням не пишаються. Воно тотожне переживанню власного життя. «Життя і покликання повинні мати зв'язок. - Каже педагог. Для того, щоб людина відчувала себе щасливою до кінця свого життя, в неї має бути покликання».

Свген протягом 13 років викладає іноземну мову в школі. Працювати за покликанням - це для нього спосіб жити чесно, робити те, що дійсно подобається, бути майстром своєї справи і служити людям. Робота 
вчителя особливо вимоглива, тому що «діти - це той лакмусовий папірець, який ніколи не дасть вам збрехати, вони відразу помічають ваші помилки». Лише той вчитель, який прагне пізнання світу і себе, може зацікавити учнів у вивченні свого предмету. «В моєму випадку англійська мова - це засіб спонукати дітей до розуміння і пізнання більшого, ніж сам цей предмет». На переконання Євгена, кожен предмет навчання має відкривати можливості для розвитку та свідомої участі майбутньої дорослої людини у суспільному житті: «тому що всі знання, як цеглинки і альтернативи, стають основою, на якій людина може робити свій суспільно-корисний вибір, власне, розуміючи свої інтереси, свої вміння, навички і маючи бажання ними поділитися у суспільстві».

Вчитель усвідомлює суспільне значення своєї професії, але він має передусім внутрішню потребу навчати. «Е внутрішній поклик навчити, зробити людину кращою, в деяких випадках повернути віру в себе, в деяких - укріпити іiі, в інших випадках пояснити щось...» Бути вчителем - це покликання, а бути на роботі вчителя - не завжди наслідок покликання. Однак, на думку Свгена: «робота вчителя не за покликанням - це надзвичайно важно. Навіть пасивна людина довго не витримає тут без покликання».

Мета вчителювання - «пробудити інтерес, мотивацію позитивну, вкласти знання і окрім того дати спонукання, бажання діяти далі в цій сфері...» Вчитель кожного разу стоїть перед викликом «чи зможу я?» Його успіх - «це дійсно надзвичайне відчуття, ти усвідомлюєш, що у цьому суспільстві ти займаєш дійсно своє місце... за яке тобі подякують».

Розмову з Євгеном можна резюмувати наступним чином: покликання вчителя - пробуджувати в молодих людях їхнє покликання. І це спосіб зробити їх щасливими.

Світлана працює вчителем 30 років. Вчительство іiі доля, адже дитинство пройшло у школі в подвійному сенсі - вчителькою була її мама. Вибір полягав лише у тому, який предмет обрати за професію. Покликання Світлана знайшла у викладанні української мови та літератури. Працюючи все життя у школі з російською мовою викладання в Києві, Світлана навчає не лише російськомовних дітей, але й багато дітей з різних іноземних родин. Це їі місія - залучати неукраїнських дітей до української мови і культури. «Мені дуже приємно повертати людей до українства».

Покликання йде від серця, від емоцій, з природою закладених у кожній людині здібностей, вважає Світлана, пригадуючи думки Г.С.Сковороди. Однак, завдання вчителя не лише допомагати молодим людям пізнавати себе, але й у тому, щоб показати можливі шляхи розвитку, дати спрямування до того, щоб вони були свідомими громадянами, патріотами своєї землі та культури. Вчитель покликаний у свій спосіб нести добро у світ - через передачу знань, виховання. Він має постійно 
вчитися, щоб навчати інших. Вчитель має бути сильною людиною, щоб долати труднощі і досягати своєї мети. Він також має всюди пам'ятати про честь своєї професії. Світлана каже: «Я не можу собі поза школою дозволити поведінку, цілком прийнятну в суспільстві, але яка не личить вчителеві. Ти завжди в мундирі». Така підвищена відповідальність і буденна праця мають винагороду - на життєвому шляху вчителя сяють «діамантики, зірочки» успіхів його учнів.

Вчитель, у собі та в учнях, спрямовуючи бажання, розвиваючи здібності, досягаючи результатів, що служать певному благу, яким би його не визначила людина - особистим, духовним, суспільним - реалізовує своє покликання. Виявлена структурна цілісність феномену покликання отримує у нашому спілкуванні з вчителями підтвердження. $E$, втім, невеликий, але важливий додаток до мотивації у малоприбутковій справі педагога - подяка - «мені навіть за це подякують...» Авжеж, старший колега колись казав Світлані: «Про вчителів складають пісні». Про кого ще? Подяка - та оцінка, на яку суспільство за будь-яких умов спроможне - $€$ і побажанням, і настановою стосовно ставлення до праці вчителів.

Лідія працює педагогом 32 роки. Покликання - це внутрішній вогник, який вона несе через життя. Він може горіти яскраво, часом слабнути, але ніколи не зникає. Вогник покликання не залишається прихованим, завжди знаходить вихід у світ і впливає на оточуючих. «Це йде від мене, та я не для себе це роблю. Це моє внутрішнє поривання, я хочу це зробити, але на благо інших».

Покликання в людини одне, хоч і може виявлятися у різних формах. Маючи здібності до малювання, успішний досвід творчої роботи, Лідія використовує їх у покликанні до соціальної педагогіки. Її авторські розробки з арт-терапії поєднуються з виховною роботою. Так покликання не вимагає жертв здібностями, яких у людини може бути багато, а саме розвиває їх. Лідія на своєму досвіді показує, що покликання інтегрує різні таланти людини, ставить їх на службу меті їі життя. «Чим би я не займалася, напрямок в мене один - це педагогіка». Попри перспективи адміністративної кар'єри, наша співрозмовниця залишилася в практичній роботі, і не шкодує про це. Її тримає у покликанні соціального педагога бажання допомагати людям і воля досягати позитивного результату, адже метою є благо дітей та їх родин.

Лідія стверджує: «Педагог має бути переможцем, не домінатором, але людиною спроможною ризикувати і досягати мети». А мета педагога служити добру.

Христина шкільний психолог, і працює за спеціальністю всього 1,5 роки. Консультування з вибору професії і відповідно обговорення теми покликання - це частина їі роботи зі старшокласниками. Христина на- 
магається сприяти розумінню молодими людьми, як їм реалізувати себе у соціальному середовищі, у якій справі, для кого. І в роботі у школі, i, працюючи з дорослими поза нею, психолог не вчить. Її завдання допомагати людям усвідомити щось важливе у житті, підвести до думки про це.

«У кожної людини є те, для чого вона прийшла у цей світ. I те, що вона може зробити, привнести у світ - це і є їі покликання. Це якась унікальність, пї специфіка, яку вона може реалізувати у певній сфері, у якійсь діяльності...» - міркує Христина. Покликання не можна прорахувати наперед, але й без нього немає напрямку. Молодий психолог дає такий образ: «Їдеш на машині, й темно... Якусь дорогу ти попереду бачиш, але не знаєш, що там далі (ями, перепони), та все одно не повернеш зі свого шляху». Так і в покликанні ти йдеш, і перед тобою є світло, йдеш, не зважаючи на невідомість попереду. Покликання - це те, що тобі дозволяє йти далі, те, що у житті дає світло попереду.

«Смак життя, вся його краса і багатогранність саме в цьому, а вже як обирає людина, це іiі право, - веде свою думку Христина, - “загнати” всіх у покликання неможливо. До цього людина має прийти. Зовнішні обставини можуть підштовхувати, підказувати, вони можуть “волати”, але людина робить інший вибір. Обрати чи ні, йти цим шляхом або не йти, вона вирішує на свою відповідальність».

\section{Покликання як критерій оцінки педагога та чинник розвитку освіти}

Підсумовуючи досвід спілкування з майбутніми та нинішніми педагогами, поміркуємо про те, як можливо врахувати чинник покликання у практиці підготовки, відбору й оцінки вчителів та у реформуванні освітньої галузі. Наведені тут і далі висновки належать не лише автору статті, але є переважно думками учасників проведених інтерв’ю.

Як свідчать практикуючі вчителі, через 3-5 років роботи відбувається відсів тих, хто не зважив на майбутні труднощі, переоцінив своє бажання їх долати, а більшість тих, хто лишається, мають покликання до своєї справи. Звісно, не всі вчителі працюють за покликанням, хоча суспільство потребує, щоб у школах та вишах були саме такі люди. Високі очікування стосовно цієї професії зрозумілі. Від роботи вчителя залежить те, якими будуть наступні покоління громадян, з якими вміннями, знаннями та, головне, з яким світоглядом вони увійдуть до суспільного життя. Результатом педагогічної роботи є соціальна зрілість, відповідальність, творчий потенціал молодих людей. Для розвитку особистості учня вчитель має виходити за рамки свого предмета викладання. А той, хто не має покликання до педагогічної роботи, не буде перейматися вихованням та особистісною зрілістю учнів. 
Покликання вимагає саморозвитку вчителя і відповідно спонукає розвивати учнів. Викладач без покликання - причина деградації школярів та студентів, втраченого чи нерозвиненого інтересу до знань, небажання молодих людей до громадянського становлення. Як відзначала одна з опитаних студенток: «Робота за покликанням $є$ творінням, а робота без покликання є руйнуванням себе та інших». Ще одна наша співрозмовниця каже: «Людина за покликанням приносить гармонію. Людина у цій справі поводить себе з любов’ю». Інший учасник інтерв’ю переконаний: «Працюючи за покликанням, людина отримує моральне задоволення і радість, і дає те ж саме іншим».

Покликання відповідальне. На прикладі вчительства ми ясно бачимо цю відповідальність людини за свою професію, за тих і перед тими, кого вона стосується. Студентка Дарія говорить: «Якщо я стану добрим вчителем, це означатиме, що я реалізую своє покликання, i що я матиму відповідальність за свою професію та за дітей». Інша студентка, Софія, надає відповідальності особливого значення: «Відповідальності достатньо у своїй справі, не обов'язково називати ії покликанням - треба робити щось корисне, долати труднощі - це і є людське життя. У цьому воно має сенс і виправдання». Але чи досить бути просто відповідальним професіоналом для роботи вчителем? 3 цим не погоджуються решта наших респондентів. Вчительство вимагає більшого, ніж лише викладання та виконання інших посадових обов'язків на цій роботі. Ось слова Ірини, вчительки з великим стажем роботи: «Якщо вчитель гарно знає методику і матеріал, провів урок, і його після уроку більш нічого не хвилює, то це не покликання. Покликання спонукає переживати про дітей, думати після уроків про роботу». І лише так можливо досягти того, щоб учні у навчанні бачили не лише процес засвоєння учбового матеріалу, але можливість особистого розвитку, пізнання світу, громадянського становлення. Саме в цьому і полягає сенс освіти.

Отже, покликання у педагогічній роботі важливе. Чи можемо ми вимагати доказів покликання від педагогічних працівників? Ми вже згадували про природний відбір у школах, де важко втриматися, не маючи внутрішніх спонукань до цієї роботи. Правда, деякі люди залишаються працювати вчителями навіть тоді, коли ця робота їм не до душі. На жаль, такі є у кожній школі. Виявити їх нескладно, перш за все за успіхами учнів, за тим, як вони себе поводять на уроках вчителя, чи мають вони інтерес до його предмету. Для відсіву неспроможних педагогічних працівників атестації було б достатньо, погані результати приховати важко.

Але коли йдеться про гідних просування та заохочення педагогів, тут формальними оцінками ї роботи не обійтися. Усі сертифікати й тестування не засвідчать ставлення до праці та до учнів. Вчительство, коли 
воно є успішним, не просто робота, де виконують певні функції, воно потребує всієї особистості педагога, а просто кажучи, вимагає віддавати своїй справі «частинку душі». Без цього піднесення, виходу поза межі рутини вчительство - важкий тягар, або й, за словами наших співрозмовників, «жах» і для самого педпрацівника, і для його учнів. Для того, щоб побачити вчителя за покликанням не потрібні тестування, які вимагали б операціоналізації цього складного поняття. Достатньо спостерігати педагога безпосередньо за роботою, серед дітей.

Отже, постає питання: чи варто взагалі покликання робити критерієм оцінки педагога? Як ми відзначали, нездарного вчителя нескладно виявити за допомогою наявних атестаційних процедур. А вчителя, який спроможний виконувати свою роботу, перевіряти на покликання немає сенсу. По-перше, з великою ймовірністю покликання він відчуває. Подруге, не лише в Україні, але й по заможніших країнах світу є брак вчителів. Тому гребувати педагогами, які бодай формально справляються зі своєю роботою, недоцільно. По-третє, і це найважливіше розуміти, вимагати доказів покликання від будь-якої людини неетично. Покликання існує у царині особистісної свободи, до нього не примушують.

На початковому етапі роботи молодому спеціалісту потрібний час, щоб самому пересвідчитися в тому, чи вірно він обрав свій професійний шлях. Людині має бути надана можливість випробувати себе і прийняти рішення, залишатися в обраній професій, рости у ній, чи шукати іншу роботу. В студентські роки, так чи інакше 3 майбутніми спеціалістами проводиться роз'яснювальна робота щодо вимог та моральних складнощів майбутньої професії, є педагогічна практика. Якщо людина вже прийшла працювати за цим фахом, в неї має бути шанс у ньому утвердитися. I звісно ставити покликання за критерій допуску до роботи не буде вірно. Навпаки, момент довіри, презумпція покликаності має бути стосовно кожного, хто відповідає професійним та психологічним вимогам, входячи у вчительську професію. Моральний тиск, яким би було доведення свого покликання для інших, тут неприпустимий. Інакше можливо втратити майбутніх хороших і просто адекватних вчителів, яких і поза тим недостатньо. Результати їх праці покажуть все - це атмосфера взаємоповаги з учнями, інтерес до роботи та навчання, який теж завжди взаємний. Вчитель за покликанням виявить те краще, що кожен, на жаль не завжди і лише в окремих випадках, пам'ятає зі своїх шкільних років.

Де ж тоді актуальність піднятої теми? Даруйте, так само риторично можна питати про стан культури, громадянської свідомості. Проте пояснити ситуацію нескладно. Культура і освіченість не витворюються через формальні заходи, але їх не буде без суспільної уваги і в тому числі без підтримки їх розвитку державними та приватними засобами. Шо можна 
і потрібно робити для того, щоб зокрема в освітній галузі покликання ставало чинником іiі розвитку? Перш за все - це створити атмосферу свободи. Покликання немає, де скута свобода і творчість, де все поставлено під прес планів та виконання стандартних вимог. І студенти, і вчителі у спілкуванні не раз відзначали зарегульованість педагогічної роботи - тяжіння над нею формальностей, затверджених планів, писанини, i, поготів, невластивих вчителеві господарських та подібних їм функцій, які доводиться виконувати за рахунок улюбленої праці, замість часу й простору для творчості та спілкування з учнями. Якщо вчитель буде займатися лише справою свого покликання, його бажання і радість від роботи буде помножена на відгук в серцях тих десятків та сотень учнів, до долі яких він на своєму місці у цьому світі причетний.

\section{Висновки}

Покликання як феномен людського існування має складну структуру, яка включає такі елементи: Бажання-Талант-Реалізація-Благо. Якщо немає одного з цих елементів, не існує й покликання. Мало бути до чогось схильним, потрібно мати хист, потрібна праця, потрібна реалізація й розуміння, яку користь, благо, кому й для чого це приносить. Структурне ціле виявлених елементів утримується наскрізним стрижнем мети. Ця мета - те благо, до якого прямує людська діяльність, вона ж - і перший поштовх, і енергія не зупинятися. Мета покликання, в чому переконані учасники дослідження, є такою, що веде людину поза особисті межі, формує відкритість і готовність йти за нею, наскільки сягає світло попереду.

У тексті ми не давали власне визначення покликання, прагнучи через цитати наших співрозмовників висловити різні аспекти цього феномену. Однак тепер, відповідаючи на потребу мати опорні точки для подальшої дискусії, пропонуємо визначення: покликання - це смислове ціле, яке об'єднує особисті бажсання, здібності, діяльність для їх реалізаиї та оцінку досягнених результатів відповідно до розуміння людиною особистісного, суспільного або духовного блага, на яке вони спрямовані. Як і будь-яке інше визначення, це, що ми дали, провокує на критику та наражається на спростування. Так і має бути, щоб розмова на запропоновану тему не припинялася.

Покликання педагога - це приводити молодих людей до їх власних покликань. Сутність освіти у піднятті людей до рівня духу з рівня матерії. Так вважав Гегель, і принаймні образно (адже, що вважати рівнем духу - питання дискусійне) з цією думкою ми погоджуємося. Місія вчителя і викладача - знайти, збудити, підтримати й спрямувати здатність молодих людей до особистісного зростання, до піднесення від рівня турботи про себе до рівня піклування про благо, яке завжди більш ніж особистісне. 
Педагогічна робота потребує покликання. В умовах низьких зарплат самоповага і відчуття користі від праці грунтується на нематеріальних чинниках - розумінні власної місії у світі, внутрішній потребі у своїй справі, вдячності учнів та ін. Така мотивація до вчительської праці потрібна й у більш забезпечених країнах. Вчительство не є високооплачуваною роботою у всьому світі, порівняно з іншими професіями. Педагогічна діяльність всюди $є$ радше реалізацією внутрішньої потреби, ніж способом гарного заробітку. Не будемо брати тут до уваги тіньовий бік справ - peпетиторство, грошові побори у школах та інше. Цього очевидно немає в розвинених країнах, і це перестане бути нормою в ході реформування освітньої галузі в Україні. Що ж і хто залишиться у сфері освіти?

В період реформ в Україні саме на людей, які мають пристрасть до своєї роботи, яким небайдужий ії результат, лише й можливо спертися, запроваджуючи новації у школах та вишах. Більше того, саме такий вчитель та викладач у першу чергу буде тим, хто активно долучиться до покращення роботи у своїй галузі. В умовах обмеженого бюджету додаткова матеріальна мотивація, програми стимулювання мають бути спрямовані саме для тих, хто здатний просувати зміни. Цих людей потрібно виявляти за їх живим відгуком, за їх переконливими проектами для реалізації, можливо й через проведені атестації. Але потрібно враховувати і неформальні параметри роботи, оцінки, які дають колеги й учні, а також те, що можна побачити, спостерігаючи за вчителем у його справі.

Індикатором вірного шляху реформ буде те, що покликання стане неформальною ознакою визнання педагога, який отримає увагу і підтримку держави. Таких людей не потрібно перевіряти на покликання, треба створити умови, коли вони виявлять себе самі, маючи внутрішнє спонукання до своєї справи. Тому ідея покликання є радше регулятивною - йдучи працювати до школи чи вишу, кожен має запитувати себе про своє покликання сам, чи буде він цим займатися, не дивлячись на ті матеріальні та моральні труднощі, які доведеться долати на цьому шляху. Однак, феномен покликання не має залишатися без уваги в розробці політики реформування освіти в Україні та в напрацюванні інструментів ії впровадження.

\section{Література:}

1. Вебер М. Политика как призвание и профессия // Вебер М. Избранные произведения. - М.: Прогресс, 1990. - C.644-706. (Weber M. Politik als Beruf. Weber M. Gesammelte Politische Schriften, Tubingen, 1980, S.505-560).

2. Вебер М. Наука как призвание и профессия // Вебер М. Избранные произведения. - М.: Прогресс, 1990. - C.707-735. (Weber M. Wissenschaft als Beruf. Weber M. Gesammelte Aufsatze zur Wissenschaftslehre, Tubingen, 1952, S.572-597).

3. Вебер М. Протестантська етика і дух капіталізму. - К.: Основи, 1994. - 261 с. (Weber M. Die Protestantosche Ethik und der Geist des Kapitalismus. Weber M. Gesammelte Aufsatze zur Religionssoziologie, Tubingen, 1963). 
4. Сковорода Григорій. Твори: У 2 т. Т.1. - К.: АТ «Обереги», 1994. - (Гарвардська б-ка давнього укр. письменства). (Skovoroda, Hryhory. (1994). Works in two volumes. Kyiv: Oberehy. (Harvard Library of Early Ukrainian Literature).

5. Bigham, Jared T. and Smith, Samuel J. (2008). Called to Teach: Interpreting the Phenomenon of Calling as a Motivating Factor. Faculty Publications and Presentations. Paper 99. http://digitalcommons.liberty.edu/educ_fac_pubs/99

6. Cohen, M., Kahn, D., \& Steeves, R. (2000). Hermeneutic phenomenological research. Thousand Oaks, CA: Sage Publications.

7. Colozzi, E. A., \& Colozzi, L. C. (2000). College students' callings and careers: An integrated values-oriented perspective. In D. A. Luzzo (Ed.), Career counseling of college students: An empirical guide to strategies that work. P. 63-91.

8. Farkas, S., Johnson, J., \& Foleno, T. (2000). A Sense of Calling. Who Teaches and Why. Public Agenda, 1-16. https://www.publicagenda.org/files/sense_of_calling.pdf

9. Levoy, Gregory. (1997). Callings: Finding and Following an Authentic Life. NY, Three Rivers Press.

10. Merton, Robert K. (1960). Some thoughts on the professions in American society (Address Before The Graduate Convocation Brown University, June 6, 1960). - Brown University Papers, Number XXXVII.

11. Pascal, Jan. (2010). Phenomenology as a Research Method for Social Work Contexts: Understanding the Lived Experience of Cancer Survival. Currents: New Scholarship in the Human Services (La Trobe University, Australia), Volume 9, Number 2, 1-23.

12. http://www.academia.edu/3476857/Phenomenology_as_a_research_method_for_ social_work_contexts_Understanding_the_lived_experience_of_cancer_survival

13. Teneva, Maria. (2013). The choice of a pedagogical profession, Trakia Journal of Sciences, No 3, P. 282-285.

14. http://www.uni-sz.bg/tsj/N3,\%20Vol.11,\%202013/M.Teneva.pdf

15. Van Manen, M. (1990). Researching Lived Experience. Albany, NY: SUNY Press.

16. VanOosting, James. (2002). Vocation Education. America, 187, P. 8-11. http://www. americamagazine.org/issue/377/article/vocation-education

\section{Евгений Мулярчук. Призвание как мотивационный фактор развития обра- зования в Украине.}

В статье ставится проблема нематериальной мотивации профессиональной деятельности, в частности, в сфере образования. Решается задача определить значение призвания для ученической молодёжи, студентов педагогического профиля и практикующих учителей. Изучены мотивы выпускников школ и студентов в отношении их образования и будущей работы. Для выявления и анализа непосредственного опыта призвания студентов и учителей применяется метод глубинных интервью. В результате исследования доказана значимость идеи призвания для ученической и студенческой молодёжи в Украине, а также её релевантность опыту практикующих педагогов. Установлена структура феномена призвания как единства элементов: Желание-Талант-Реализация-Благо. Для дальнейшей дискуссии предложено определение понятия призвания. Показаны возможные пути использования мотивационного фактора призвания для реформирования системы образования в Украине. 
Ключевые слова: феномен призвания, самореализация, опыт, мотивация, ответственность, общественная польза, благо, педагогическая деятельность, реформа образования.

Yevhen Muliarchuk. Mission as a Motivating Factor of the Development of Education in Ukraine.

The article raises importance of the topic of mission in contemporary philosophy and educational sciences. Mission is a basic idea for building up of civil society as a community of responsible and committed people. Mission has a special significance for teaching professions. Ukraine as well as many other countries experiences a shortage of teachers. Many successful students of pedagogical professions prefer to get other jobs because of low salaries and prestige of teaching. The problem of motivation in educational sphere needs political, public and scientific awareness.

The skeptics and pragmatics are not sure that mission is a vital idea of our days. That is why it was important to find out whether the phenomenon of mission exists in the consciousness of contemporary Ukrainians and how it appears to them. In the focus of the article are opinions of secondary school graduates, students, whose area is educational sciences and professional teachers. The method and strategy of the presented research is hermeneutic phenomenology. The relevant experience of people was examined and interpreted by in-depth interviews. Before in-depth interviews there was conducted a quantitative survey which provided the statistical data about the choosing factors of future professions and the share of those who declare having the experience of mission.

The result of the survey is that at least half of Ukrainian youth think that the idea of mission is important for their choice of profession. Mission as a phenomenon shows the unity of structural elements: Desire - Talent - Realization - Social or Spiritual Benefit. The aim of transpersonal goodness is the core of the phenomenon of mission and the integrity of its structure. Teaching as a career definitely needs mission, even though it is not true for some teachers. That is undoubted thesis for Ukrainians. Teacher's mission is to bring young people to their own missions. If the essence of education is a rising people to the level of spirit out of the level of matter, the task of a teacher is to bring up that ability of that rising in the youth. People of mission are those who have to be in the center of the development of education system reforms in Ukraine.

Keywords: phenomenon of mission, self-actualization, lived experience, motivation, responsibility, social benefit, spiritual benefit, goodness, teaching, reform of education.

Мулярчук Свген Іванович, кандидат філософських наук, старший науковий співробітник Інституту філософії ім. Г.С.Сковороди НАН України.

E-mail: muliarchuk.yevhen@gmail.com.

Muliarchuk Yevhen Ivanovych, PhD in Philosophy (Ethics), Senior research fellow of H.Skovoroda Institute of Philosophy National Academy of Sciences of Ukraine.

E-mail: muliarchuk.yevhen@gmail.com. 